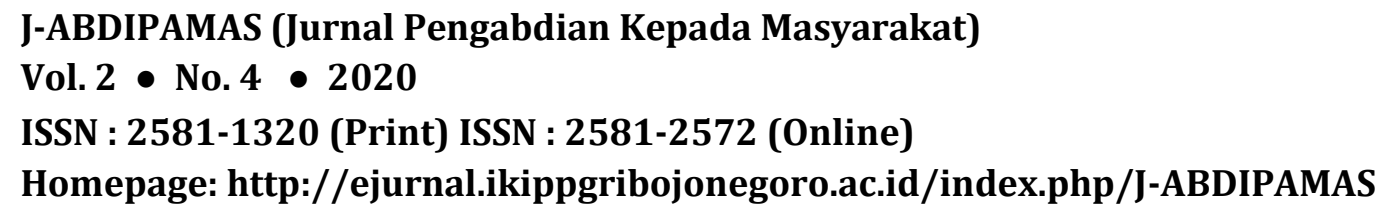

\title{
PENYULUHAN KESEHATAN DAN GIZI ANAK USIA DINI BAGI ORANG TUA DAN GURU PADA MASA COVID-19
}

\author{
M. Fadlillah ${ }^{1}$, Dian Kristiana ${ }^{2}$, Betty Yulia Wulansari ${ }^{2}$ \\ ${ }^{1}$ Universitas Muhammadiyah Ponorogo. Email: fadly_ok@yahoo.co.id \\ 2Universitas Muhammadiyah Ponorogo. Email: dianrespati@ymail.com \\ 3Universitas Muhammadiyah Ponorogo. Email: bettyyulia22@gmail.com
}

\begin{abstract}
Early childhood has very rapid growth and development. During this period children need health services and balanced nutritional intake so that they can develop physically and mentally optimally. Parents and teachers as the child's closest environment have a very central role in children's health and nutrition, especially during the Covid-19 pandemic. This extension activity is intended to increase the knowledge, understanding and skills of parents and teachers in providing health and nutrition services for early childhood. It is hoped that parents and teachers can play an active role in maintaining children's immunity by meeting health and nutritional needs so that they can prevent the spread of the Covid-19. In addition, by getting adequate nutrition, children can grow and develop optimally. The method used in health and nutrition education is online webinars using google meet media. This activity was attended by 57 participants with two resource persons in the fields of health and early childhood education. Each resource person delivered material briefly for 20-30 minutes and continued with questions and answers for 45 minutes. The results of this outreach activity were: parents and teachers were very enthusiastic about participating in the webinar which was held on July 17, 2020 from 09.00 to 11.30 WIB. In addition, parents and teachers obtain material and an understanding of the needs of balanced health and nutrition for early childhood at home and at school.
\end{abstract}

Keywords: counseling, parents and teachers, health and nutrition, early childhood, Covid-19

\begin{abstract}
ABSTRAK
Anak usia dini memiliki pertumbuhan dan perkembangan yang sangat pesat. Selama periode tersebut anak membutuhkan layanan kesehatan dan asupan gizi seimbang supaya fisik dan mentalnya dapat berkembang optimal. Orang tua dan guru sebagai lingkungan terdekat anak memiliki peran sangat sentral terhadap kesehatan dan gizi anak, lebih-lebih di masa pandemi Covid-19. Kegiatan penyuluhan ini dimaksudkan untuk meningkatkan pengetahuan, pemahaman dan keterampilan orang tua maupun guru dalam memberikan layanan kesehatan dan gizi bagi anak usia dini. Harapannya orang tua dan guru dapat berperan aktif dalam menjaga imunitas anak melalui pemenuhan kebutuhan kesehatan dan gizi sehingga dapat mencegah penyebaran Covid-19. Metode yang digunakan dalam penyuluhan kesehatan dan gizi ini adalah webinar online dengan menggunakan media google meet. Kegiatan ini diikuti oleh 57 peserta dengan dua narasumber di bidang kesehatan dan pendidikan anak usia dini. Masing-masing narasumber menyampaikan materi secara singkat selama 20 - 30 menit dan dilanjutkan tanyajawab selama 45 menit. Hasil kegiatan penyuluhan ini yaitu: orang tua dan guru sangat antusias dalam mengikuti webinar yang dilaksanakan pada tanggal 17 Juli 2020 dari pukul 09.00 sampai 11.30 WIB. Orang tua dan guru memperoleh materi dan pemahaman tentang kebutuhan kesehatan dan gizi seimbang bagi anak usia dini di rumah maupun di sekolah.
\end{abstract}

Kata Kunci: penyuluhan, orang tua dan guru, kesehatan dan gizi, anak usia dini, covid-19 


\section{PENDAHULUAN}

Kesehatan dan gizi bagi anak usia dini sangat penting karena mampu menunjang pertumbuhan dan perkembangannya secara optimal. Kesehatan dan gizi merupakan kebutuhan esensial anak yang harus terpenuhi dengan baik, di samping pendidikan, pengasuhan maupun perlindungan (Kemendikbud, 2015). Mengingat begitu pentingnya kesehatan dan gizi ini pemerintah Indonesia mengeluarkan Peraturan Presiden Republik Indonesia Nomor 60 Tahun Tahun 2013 tentang Pengembangan Anak Usia Dini Holistik Integratif. Di mana di dalamnya terdapat ketentuan mengenai layanan kesehatan dan gizi yang wajib dilaksanakan oleh orang tua, guru maupun masyarakat.

Kesehatan dan gizi adalah salah satu faktor utama yang mempengaruhi perkembangan anak. Manakala kebutuhan kesehatan dan gizi anak tidak terpenuhi dapat mengganggu dan menghambat berbagai perkembangannya (Inten dan Permatasari, 2019). Anak usia dini merupakan masa-masa yang rentan terhadap serangan penyakit baik virus maupun bakteri (Andante, 2018). Oleh karena itu, anak membutuh gizi yang seimbang supaya tetap sehat dan memiliki perkembangan yang optimal. Dengan pemberian gizi seimbang, layanan kesehatan dan perawatan yang baik dapat menjadikan anak tumbuh dan berkembang secara optimal (Prima, 2017). Zat gizi dari makanan merupakan sumber utama untuk memenuhi kebutuhan tumbuh kembang anak sehingga dapat mencapai kesehatan yang optimal, meliputi: sehat fisik, mental, dan sosial (Andante, 2018).

Pemahaman orang tua terhadap kebutuhan kesehatan dan gizi anak usia dini masih sangat terbatas, sehingga dalam merawat dan mengasuh anak-anak mereka cenderung tidak maksimal. Masih banyak orang tua yang kurang peduli terhadap kesehatan dan gizi anak. Hal ini sejalan dengan masih banyaknya jumlah anak yang mengalami gizi buruk dan stunting. Berdasarkan data yang dirilis oleh Danone Indonesia, menyebutkan sekitar 17,7 persen balita di Indonesia masih mengalami gizi kurang dan gizi buruk, bahkan 30,8 persen terindikasi stunting. Di luar itu, sekitar 55 persen balita mengalami kekurangan energi, dan lebih dari 80 persen anak usia 4-12 tahun kekurangan Eicosapentaenoic Acid (EPA) + Docosahexaenoic Acid (DHA) (Suleha, 2019). EPA dan DHA meruakan nutrisi untuk perkembangan otak anak (Fauzi, 2018). Selain itu, Kementerian Kesehatan mengungkapkan bahwa Di Indonesia, kekurangan gizi menurut berat badan per usia mencapai 17\% melebihi batas WHO 10\%. Kategori kedua, indeks tinggi badan per usia, angka kekurangan gizi masih tinggi, yaitu 27.5\%. Adapun batas WHO adalah 20\%. Pada kategori ketiga, yaitu indeks berat badan per tinggi badan pun masih di atas batas WHO, angka kekurangan gizi mencapai $11 \%$, sedangkan batas WHO adalah 5\% (Inten dan Permatasari, 2019).

Berbagai permasalahan kesehatan dan gizi anak usia dini banyak terjadi salah satunya dipengaruhi oleh pola asuh orang tuanya. Menurut Suleha (2019) pola pengasuhan anak usia dini dapat berpengaruh besar terhadap asupan gizi seimbang yang akan menentukan pertumbuhan dan perkembangan anak. Artinya, orang tua memiliki peran sangat penting bagi kesehatan dan gizi anak. Orang tua berkewajiban memberikan nutrisi yang seimbang bagi perkembangan anak. Untuk mengatasi berbagai 
permasalahan tersebut maka orang tua perlu mendapatkan sosialisiasi atau penyuluhan tentang kesehatan dan gizi anak usia dini.

Berdasarkan uraian diatas, kegiatan pengabdian masyarakat ini merupakan sebuah upaya untuk meningkatkan pengetahuan orang tua dan guru tentang kesehatan dan gizi anak usia dini. Dengan memiliki pengatahuan yang memadai harapannya orang tua dan guru dapat peduli dan berperan aktif dalam memenuhi kebutuhan dan kesehatan gizi anak supaya imunitas tubuhnya bertambah sehingga dapat mencegah terjadinya penyebaran Covid-19 pada anak usia dini. Di samping itu juga untuk mengurangi angka gizi buruk dan stunting di Indonesia.

\section{PERMASALAHAN MITRA}

Pada masa pandemi Covid-19 penyuluhan kesehatan dan gizi anak usia dini bagi orang tua dan guru sangat diperlukan. Tujuannya adalah untuk membantu dan memberikan wawasan kepada orang tua maupun guru dalam memenuhi kebutuhan kesehatan dan gizi anak. Apabila kesehatan dan gizi anak terpenuhi akan mampu meningkatkan imunitas tubuhnya sehingga tidak mudah tertular penyakit Covid-19. Sayangnya, pemahaman terhadap kesehatan dan gizi anak usia ini belum sepenuhnya dimiliki oleh masyarakat, khususnya orang tua dan guru. Berdasarkan pengamatan dan berbagai diskusi menunjukkan bahwa:

1. Sebagian orang tua dan guru belum mengerti tentang kebutuhan kesehatan dan gizi anak usia dini pada masa pandemi Covid-19.

2. Pemahaman orang tua terhadap program-program kesehatan dan gizi yang dapat menunjang pertumbuhan dan perkembangan anak masih terbatas.

3. Sebagian masyarakat belum menerapkan protokol kesehatan Covid-19 dengan benar, termasuk menjaga kebersihan diri dan lingkungan.

Melalui kegiatan penyuluhan ini harapannya banyak masyarakat, terutama orang tua dan guru dapat memenuhi kebutuhan kesehatan dan gizi anak usia dini. Di samping juga memberikan wawasan tentang protokol kesehatan pencegahan Covid-19. Dengan demikian dapat mengurangi bahkan mencegah terjadinya penyebaran virus corana pada anak usia dini di masyarakat.

\section{METODE KEGIATAN}

Kegiatan penyuluhan kesehatan dan gizi anak usia dini ini dilakukan dengan menggunakan metode webinar secara online. Adapun platform yang digunakan sebagai media webinar yaitu google meet. Dalam webinar ini peserta utamanya adalah orang tua dan guru anak usia dini. Peserta webinar ditentukan secara acak dengan mengisi form pendaftaran yang sudah disediakan. Setelah itu, direkap jumlah pendaftarnya dan dihubungi melalui email untuk mengikuti kegiatan webinar. Teknis pelaksanaan webinarnya yaitu masing-masing narasumber menyampaikan materi secara online selama 30 menit, kemudian dilanjutkan dengan tanya jawab peserta webinar selama 45 menit. 


\section{HASIL PENGABDIAN}

Kegiatan pengabdian masyarakat ini dilaksanakan pada hari Jum'at, 17 Juli 2020 bertempat di Universitas Muhammadiyah Ponorogo. Acara ini berlangsung secara online dengan menggunakan media google meet. Waktu penyuluhan berlangsung selama 2,5 jam, yaitu dimulai pukul 09.00 - 11.30 WIB.

Kegiatan penyuluhan kesehatan dan gizi ini diikuti oleh 57 peserta yang berasal dari berbagai daerah dengan latar belakang profesi yang berbeda-beda. Mulai dari orang tua, guru, penilik, pengawas, dosen dan mahasiswa. Adapun mayoritas peserta adalah guru pendidikan anak usia dini. Peserta perempuan berjumlah 49 orang dan 8 orang peserta laki-laki. Peserta yang berasal dari guru berjumlah 34 orang, penilik PAUD dari dinas pendidikan berjumlah 5 orang, pengawas RA dan BA Kementerian Agama berjumlah 4 orang, dari kalangan dosen 6 orang, dan mahasiwa 8 orang. Prosentase peserta penyuluhan terschut dapat dilihat pada gambar 1 berikut:

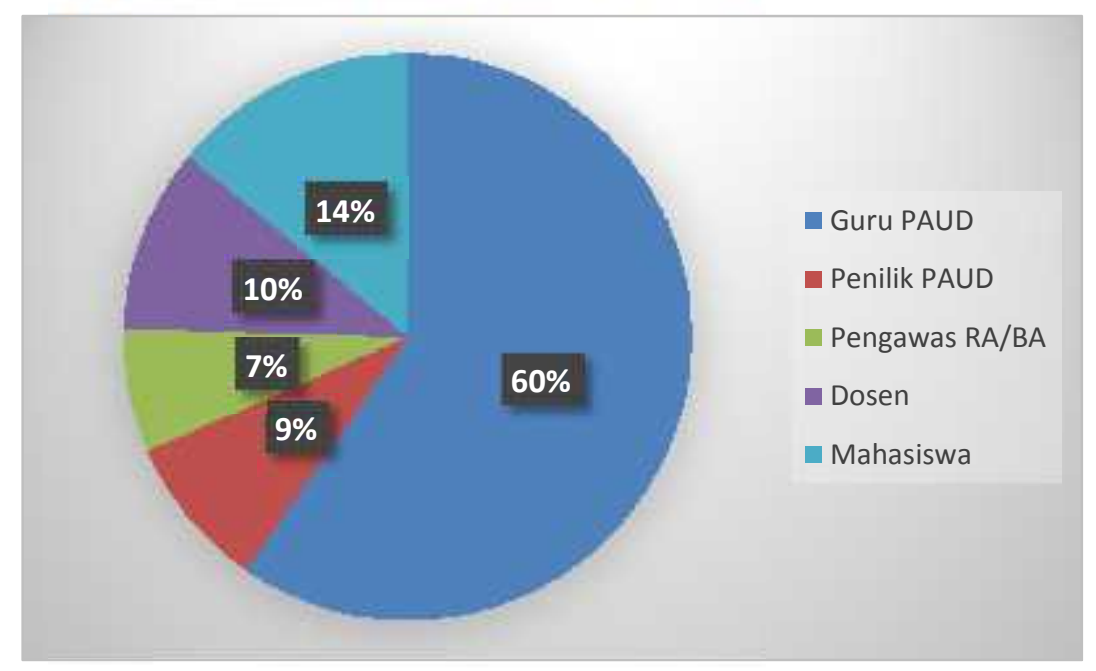

Gambar 1. Prosentase Peserta Penyuluhan Kesehatan dan Gizi

Kegiatan penyuluhan kesehatan dan gizi ini dibagi menjadi 3 sesi, yaitu pembukaan, presentasi narasumber, dan tanya jawab. Sesi pembukaan dimulai pukul 09.00 sampai pukul 09.30 WIB. Pada sesi ini kegiatan penyuluhan dibuka langsung oleh ketua program studi Pendidikan Guru Pendidikan Anak Usia Dini yaitu Dian Kristiana, M.Pd. Setelah acara pembukaan dilanjutkan dengan sesi presentasi narasumber. Presentasi pertama disampaikan oleh Dr. Sugeng Mashudi, M.Kes dari dosen Fakultas Ilmu Kesehatan Universitas Muhammadiyah Ponorogo. Pada presentasi pertama ini disampaikan makalah berjudul Gizi dan Kesehatan. Waktu presentasi yaitu selama 30 menit, yaitu dari pukul 09.30 sampai 10.00 WIB. Dalam presentasinya, Sugeng Mashudi menyampaikan bahwa keluarga sangat berperan penting dalam menjaga kesehatan dan memenuhi kebutuhan gizi anak. Budaya hidup sehat dalam keluarga akan mengurangi tertularnya Covid-19. Di samping itu, pola asuh orang tua juga sangat menentukan. Oleh karena itu, perilaku hidup sehat harus sudah ditanamkan sejak dini mulai dari keluarga. Adapun suasana webinar penyuluhan kesehatan dan gizi ini dapat dilihat pada gambar 2 berikut: 


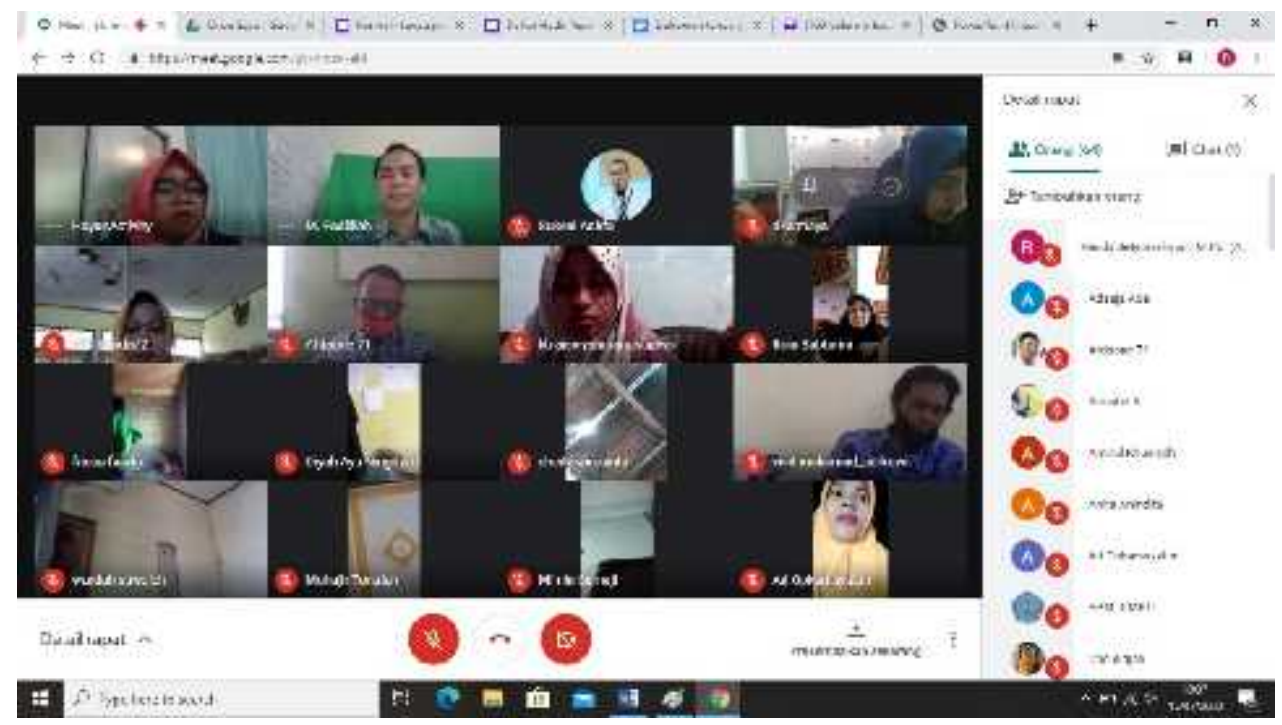

Gambar 2. Suasana Webinar Penyuluhan Kesehatan dan Gizi Anak Usia Dini

Presentasi kedua disampaikan oleh Dr. M. Fadlillah, S.Pd.I., M.Pd.I. Pada kesempatan ini dipresentasikan makalah berjudul Optimalisasi Layanan Kesehatan dan Gizi Anak Usia Dini di Satuan PAUD. Dalam presentasinya, M. Fadlillah menjelaskan bahwa guru melalui satuan PAUD harus berusaha memenuhi kebutuhan kesehatan dan gizi anak. Selain sebagai hak anak, layanan kesehatan dan gizi merupakan bagian dari program holistik integratif PAUD. Hal ini mengacu pada Peraturan Presiden RI Nomor 60 Tahun 2013 tentang Pengembangan Anak Usia Dini Holistik Integratif. Dalam peraturan presiden tersebut dijelaskan bahwa kebutuhan esensial anak usia dini harus dipenuhi, meliputi: kesehatan dan gizi, rangsangan pendidikan, pengasuhan, perlindungan dan kesejahteraan. Lebih lanjut, ia menjelaskan bahwa dibutuhkan kerjasama dari berbagai pihak supaya layanan kesehatan dan gizi dapat berjalan maksimal, di antaranya: dinas pendidikan, dinas kesehatan, orang tua, sekolah dan masyarakat. Dengan demikian kebutuhan kesehatan dan gizi anak usia dini dapat terpenuhi dengan baik sehingga mampu meningkatkan imunitas tubuhanya. Kondisi ini akan mencegah anak usia dini tertular virus corona.

\section{KESIMPULAN}

Dari kegiatan penyuluhan kesehatan dan gizi anak usia dini ini dapat disimpulkan bahwa orang tua dan guru memiliki peran sangat penting supaya anak dapat terhindar dari penularan virus corona. Dibutuhkan layanan kesehatan dan gizi yang optimal supaya pertumbuhan dan perkembangan anak berkembang sesuai harapan. Di samping itu, dengan terpenuhi kebutuhan kesehatan dan gizi dapat menambah imunitas anak sehingga akan meminimalisir penyebaran Covid-19 di masyarakat. Orang tua sebagai bagian dari lingkungan keluarga wajib membiasakan budaya hidup bersih dan sehat. Satu PAUD sebagai lembaga tempat anak bersekolah wajib memeberikan layanan kesehatan dan gizi dengan optimal. Untuk menunjang keberhasilan dalam memenuhi kebutuhan kesehatan dan gizi anak usia dini diperlukan kerjasama dari berbagai pihak, seperti dinas pendidikan, dinas kesehatan, sekolah, orang tua dan masyarakat. 


\section{UCAPAN TERIMAKASIH}

Terimakasih kami sampaikan kepada Universitas Muhammadiyah Ponorogo yang telah mendukung terlaksananya kegiatan pengabdian kepada masyarakat ini. Kepada seluruh mitra guru-guru pendidikan anak usia dini di Kabupaten Ponorogo kami ucapkan terimakasih atas partisipasinya dalam kegiatan pengabdian masyarakat ini.

\section{DAFTAR PUSTAKA}

Adante. (2018). Pentingnya Asupan Gizi dan Makanan Sehat bagi Perkembangan Anak Usia Dini. Retreaved from http://anggunpaud.kemdikbud.go.id/index.php/ berita/index/2018 1121140316/Pentingnya-Asupan-Gizi-dan-Makanan-SehatBagi-Perkembangan-Anak-Usia-Dini.

Fauzi, M.P. (2018). Ketahui Kebutuhan EPA dan DHA untuk Perkembangan Otak Sikecil. Retreaved from https://health.detik.com/berita-detikhealth/d-4076412/ketahuikebutuhan-epa-dan-dha-untuk-perkembangan-otak-si-kecil

Inten, D.N., dan Permatasari, A.N. (2019). Literasi kesehatan pada anak usia dini melalui kegiatan eating clean. Jurnal Obsesi: Jurnal Pendidikan Anak Usia Dini. Volume 3 Issue 2 (2019) Pages 366-376. Doi: 10.31004/obsesi.v3i2.188

Kemendikbud. (2015). Petunjuk Teknis Penyelenggaraan Paud Holistik Integratif di Satuan PAUD. Jakarta: Direktorat Pembinaan PAUD.

Republik Indonesia. (2013). Peraturan Presiden Nomor 60 Tahun 2013 tentang Pengembangan Anak Usia Dini Holistik Integratif.

Suleha, Y. (2019). Pentingnya Pemenuhan Nutrisi Sejak Usia Dini. Retreaved from https://www.medcom.id/rona/kesehatan/4KZ6pZWK-pentingnya-pemenuhannutrisi-sejak-usia-dini 